\title{
Different molecular approaches used for detection of Escherichia coli 0157:H7 from different sources
}

\author{
Bibi Tahira, Kaleem Ullah*, Sajid Ali, Sajid Nabi, Bibi Hajira and \\ Ameer Muhammad \\ Department of Microbiology, University of Balochistan, Quetta-Pakistan \\ *Corresponding author's email: drkaleemullah@um.uob.edu.pk \\ Citation \\ Bibi Tahira, Kaleem Ullah, Sajid Ali, Sajid Nabi, Bibi Hajira and Ameer Muhammad. Different molecular \\ approaches used for detection of Escherichia coli O157:H7 from different sources. Pure and Applied Biology. Vol. \\ 6, Issue 3, pp821-840. http://dx.doi.org/10.19045/bspab.2017.60087
}

\begin{tabular}{llll}
\hline \hline Received: 04/01/2017 & Revised: 11/06/2017 & Accepted: 30/06/2017 & Online First: 07/07/2017 \\
\hline \hline
\end{tabular}

\section{Abstract}

Escherichia coli (E. coli) O157:H7 was first recognized in 1982 after investigation of two cases of hemorrhagic colitis and hemolytic uremic syndrome. E. coli $\mathrm{O} 157: \mathrm{H} 7$ the shiga toxin producing strain of $E$. coli are most commonly involved in many outbreaks of human and animal diseases with low infectious dose. Human infections caused by E. coli $\mathrm{O} 157: \mathrm{H} 7$ are due to consumption of undercooked ground beef, raw milk and raw milk products, water, cold sandwiches, vegetables, raw apple cider and person to person contact. Due to low infectious dose and different mode of transmission it is essential to develop more rapid and sensitive methods for detection of shiga toxin producing $E$. coli. In this review different molecular based detection methods are discussed. PCR speeds up the analysis time and amplify small number of microbes are described along different variations of PCR following DPCR, omitting the tedious step of DNA extraction. Genomic techniques are reviewed along further epidemiological typing like phage typing and biotyping. Biosensors provide real time detection described along with use of fluorescence and microscopy. Emerging technologies including microarray, molecular beacons and lab-on-a-chip are described along with new improvements in molecular beacons. Merits and demerits of each approach discussed are examined throughout the article.

Keywords: E. coli O157:H7; Shiga toxins; Genomics; Molecular detection

\section{Introduction}

Enterohemorrhagic Escherichia coli (EHEC) contains numerous serotypes, among which E. coli $\mathrm{O} 157: \mathrm{H} 7$ is the most common serotype causing epidemic and sporadic diseases in humans throughout North America, Japan, Scotland, United State, Canada and many parts of Europe [14]. From investigation of two outbreaks of Hemorrhagic colitis (HC), a leading cause of
Hemolytic uremic syndrome (HUS) in 1982 the E. coli $\mathrm{O} 157: \mathrm{H7}$, a shiga toxin (stx) producing E. coli (STEC) was confirmed a pathogenic bacteria [5]. Other shiga toxin producing serotypes e.g. O103, O111, O145 and $\mathrm{O} 26$ occur, increasing human pathogens in Australia, South America and Europe [6, 7]. Serotype O157:H7 are the most virulent serotype because of production of stx genes also known as Vero toxins (VT). The stx 
produced by $E$. coli $\mathrm{O} 157: \mathrm{H} 7$ in the intestine $[8,9]$, begin illness with watery diarrhea followed by bloody diarrhea called HC [10]. Sometime HC results into life threatening disease such as HUS following thrombotic thrombocytopenic purpura (TTP), renal failure and even death [11-13]. There are other strains of EHEC that are E. coli O157, yet do not show flagellar $\mathrm{H}$ antigen and named E. coli O157:NM. Most reported outbreaks created by E. coli $\mathrm{O} 157: \mathrm{H} 7$ are food born and water born [14]. Humans become infected by $E$. coli O157:H7 because of consumption of undercooked ground beef [15-17] raw milk and raw milk products [18]. Other vehicles include contaminated vegetables, water and by person to person contact [19-22]. Numerous outbreaks by $E$. coli $\mathrm{O} 157: \mathrm{H} 7$ result from contact with cattle's and their environment and petting zoos [18, 23, 24]. Investigation of different outbreaks identifies the serotype O157:H7 to be surviving at low $\mathrm{pH}$ foods
(2.5), like apple cider and mayonnaise containing food [25-28].

Serotype O157:H7 are established in low number in environment, foods and in feces of cattle's, so rapid diagnosis is essential for detection of these pathogenic bacteria [29]. A verity of methods developed includes culturing on specific media, assessing of biochemical characteristics, screening and serotyping for existence of virulence factors. However these methods are not rapid and reliable to differentiate such pathogenic strain from other stx producing E. coli. Therefore this paper describes a number of sensitive molecular techniques used for isolation and identification of STEC O157:H7 from different sources.

\section{Molecular detection of $E$. coli O157:H7}

There are several ways for detection of $E$. coli O157:H7, among which the below diagram demonstrates the main methods discussed in present review (Figure 1)

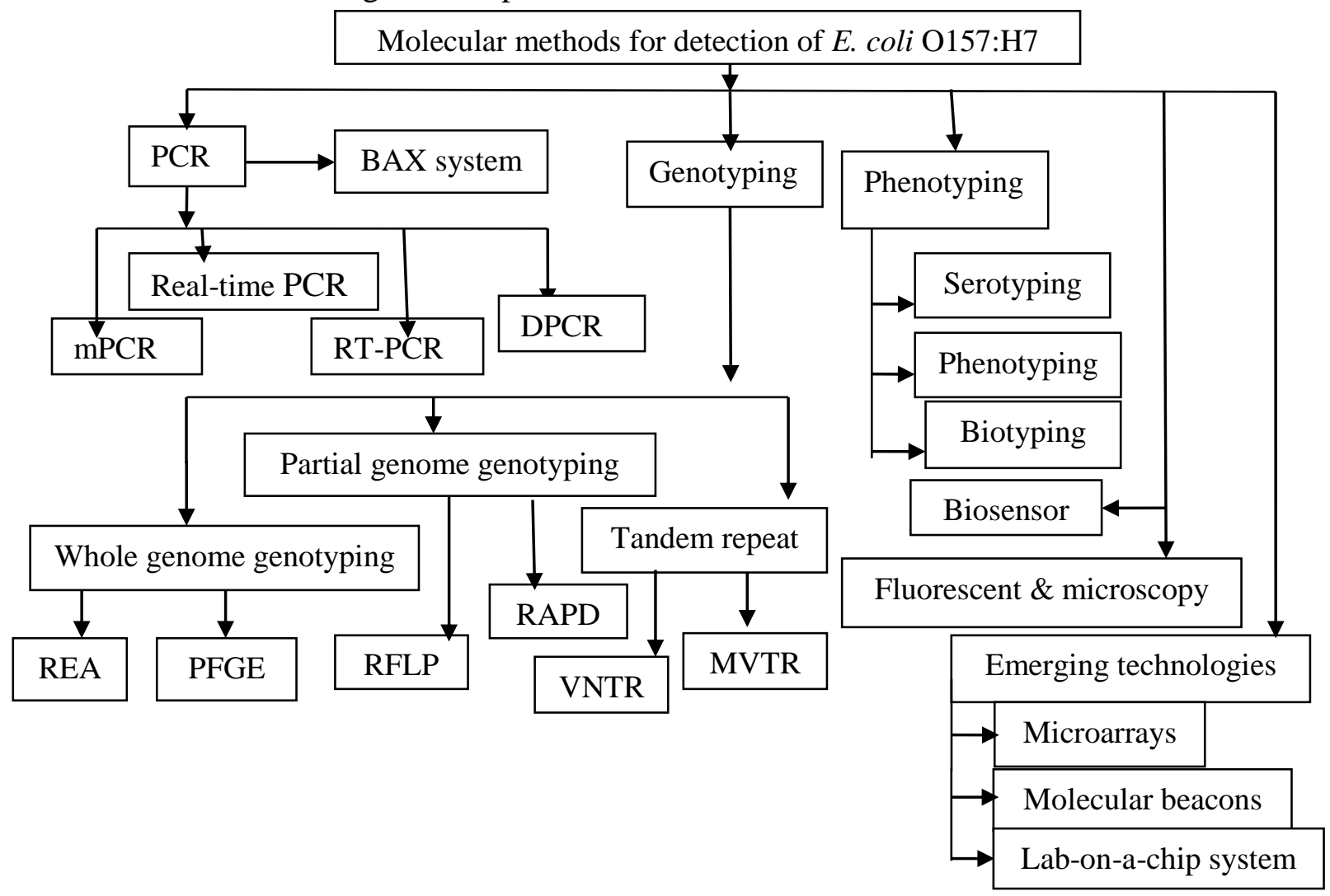

Figure 1. Molecular approaches for identification and genotyping of $E$. coli $0157: H 7$ 


\section{PCR based detection approaches}

Cultural based detection of $\mathrm{O} 157: \mathrm{H} 7$ from food and fecal samples is time consuming, labor intensive, costly and take several days for detection of bacteria. Rapid methods are used over years that replaced plating steps with enzyme immunoassay or DNA hybridization. These methods detect $10^{3}-10^{4}$ colony forming unit (cfu) per gram of required pathogen, meaning that culture based steps are still necessary. Polymerase chain reaction (PCR) has become most widely used and accurate method for identification of microorganisms. PCR based detection methods show notable advances, one of which is to speed the overall analysis time by replacing enrichment steps with amplification of specific nucleic acid sequences. The basic cause that differ PCR from previous developed methods is that from an individual bacterial cell it can amplified the DNA in around one hour. However dead cells could be amplified by PCR method but need most care during designing of experiment [30]. Additionally these build data interpretation complexes which is a difficulty that need to be directed as it hold long term inference from a forensic view. $E$. coli can survive in different unrelated environments and have the ability of surviving afar from host which allow reinfection. This important feature of $E$. coli should be approved when developing and designing real time diagnostic approaches [31]. Here we will report many approaches using this technique for detection of serotype O157:H7. The PCR assay target the 3 end of eae gene of 0157:H7. It was found more sensitive and specific due to $1 \mathrm{pg}$ DNA $/ 10^{3}$ cfu per reaction of PCR. Eventually further studies were managed to investigate the effect of sample preparation and food matrix at PCR assay recognition of heat killed $E$. coli O157:H7 (non-viable cells) from ground beef. Samples were prepared by buoyant density centrifugation (BDC), centrifugation, chelex extraction and immunomagnetic separation (IMS) methods. Among all methods IMS could not create false positive outcomes, accommodated the number of cells exist under $108 \mathrm{cfu}^{-1}$. Except the limitation of this approach was production of false positive above this number [32]. Over several years many variations of PCR has been developed for more rapid and sensitive detection of O157:H7. Among these real-time PCR and multiplex PCR are considered most popular methods. mPCR detect several target by combining or multiplexing primers pair in one PCR [33]. This type of PCR is important due to design of primers because they should to be characterized by adhering to specific DNA sequences at homogeneous temperature. However achieving this standardization of procedure requires several trials [34]. Hu et al. [35] used mPCR by using five set of primers and amplified eaeA, $f l i C$, stx 1, stx 2 and $r f b$ genes. By examining 82 strains of both E. coli $\mathrm{O} 157: \mathrm{H} 7$ and non O157, the assay developed most successful to discriminate $E$. coli $\mathrm{O} 157: \mathrm{H} 7$ from variant serotypes. Campbell et al. [36] describe mPCR for recognition of pathogenic bacteria from soil and water samples. Samples spiked with serotype O157:H7 were enriched before PCR. The recognition limit found was $1 \mathrm{cfu}$ ml-1 water and 2 cfu g-1 soil. An important feature occur was starvation serotype O157: $\mathrm{H} 7$ for about 35 days hitherto added to soil could not infect the identification of primary cell numbers as below $10 \mathrm{cfu} \mathrm{g}^{-1}$ soil. Real time PCR is developed for both identification and determination of solitary bacterial species from multiplex microbial community along from complex samples. Some researchers have possessed real-time PCR approach for detection of $E$. coli $\mathrm{O} 157: \mathrm{H} 7$ from different sources including feces, meat [37-39], crisp cultures [40] and dairy waste water dry land 
[41]. This kind of PCR uses two type fluorescence detection system, intercalating agents and probes labeled with fluorophores. Intercalating agents e.g. SYBR green fluorochromes bind to double standard DNA to increase the fluorescence. Increase of DNA reflects increase in emitted fluorescence. However intercalating agents low the specificity because of ability of binding to nonspecific products [42]. Use of probes permit identification of polymorphisms and mutations, nevertheless these are more expensive and complex than of intercalating agents. Spano et al. [43] studied cattle and dairy wastewater for identification of 0157:H7 by using real-time PCR. Samples were artificially inoculated $10^{4}, 10^{7}$ and $10^{8}$ cells $\mathrm{ml}^{-1}$ of serotype O157:H7. Extracted DNA from strain was used first to test PCR protocol to modify the amplification condition prior to real-time PCR experiments. Exact fragments of ca 106, 150 and 200 bp toward eae, stx 1 and stx2 genes subsequently were acquired. Real-time PCR protocols were conducted with DNA (extracted) from inoculated wastewater samples. The susceptibility limit

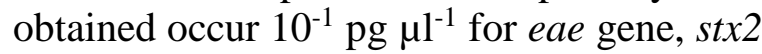
and $16 \mathrm{~S}$ rRNA and $1 \mathrm{pg} \mu \mathrm{l}^{-1}$ for stxl subsequently.

The reverse transcriptase PCR (RT-PCR) assay has been progressed for detection of $E$. coli $\mathrm{O} 157: \mathrm{H} 7$. Reverse transcriptase is an enzyme able to synthesize DNA (single standard) from RNA (especially mRNA) within 5'-3' direction [33]. However limitation of this technique is sample of mRNA, because it is known to be difficult to handle by low level and mRNA concentration and low strength at room temperature along $\mathrm{pH}$ changes [44]. RTPCR was used with Yaron \& Matthews 2002 for recognition of several genes of O157:H7, including fliC, rfbE, hly, mobA, eaeA, stx1, stx2 and 16S rRNA for viability. Stxl, rfbE, hly and 16S rRNA amplicons found to be identified in whole growth phases with creations of mobA, 16S rRNA, $r f b E$ and stxl existing imagine in RNA. However after heat treatment target $16 \mathrm{~S}$ rRNA was not magnified. The authors proposed $r f b E$ gene most acceptable target gene for identification of viable bacterial cells. RT-PCR can identify $107 \mathrm{cfu}$ of $r f b E$ gene without pre-enrichment step [45]. Such feature shows an advantage over standard PCR approaches which require enrichment step by reducing time for analysis and increase sensitivity of approach. De Wet et al. [46] used RT-PCR by developing a fast RNA extraction approach for identification of low number of O157:H7 (<30 viable cells $\mathrm{ml}^{-1}$ ) in carcass liquor except of preenrichment.

Finally direct PCR (DPCR) was described by researchers [47], an important approach for identification and quantification of microorganisms from different environmental samples. DPCR is a simple, rapid and sensitive method because target samples used directly as a template without DNA extraction. Fode-Vaughan et al. [48] used DPCR which eliminates the need for tedious steps of DNA extraction before PCR. Specific primers for stxl and st $x 2$ genes were used in DPCR assay for identification of $E$. coli $\mathrm{O} 157: \mathrm{H} 7$ from milk and environmental samples. However the limitation of direct PCR is unknown amount of DNA present in a sample, therefore should suffer from artifacts affiliated with increased sample concentration [49].

\subsection{BAX system}

The BAX system was progressed by Du Pont Qualicon (Wilmington, DE, USA) help service laboratories, food companies and government agencies for rapid identification of pathogenic bacteria from raw ingredient, environmental samples and finished products [50]. The method uses PCR technology for amplification of specific fragments of bacterial DNA. This method 
regulates presence or absence of target by using DNA amplification [51]. Johnson et al. [52] reported BAX system most batter than conventional method due to ability of detecting $96.5 \%$ compared to $39 \%$ obtained from cultured methods. However shearer $e t$ al. [53] deliberated different food samples including radish, cabbage, tomato, mango and mushrooms for detection of 0157:H7 and described BAX system more sensitive then culturing of few samples. The BAX systems are useful for identification of $E$. coli $\mathrm{O} 157: \mathrm{H} 7$ from different foods but it does not quantify presence of organisms.

\section{Genomic based methods for} genotyping of $E$. Coli O157:H7

\subsection{Whole genome genotyping}

\subsubsection{Restriction endonuclease analysis} (REA)
Restriction enzymes are commonly used for DNA mapping [54]. Different restriction enzyme are recognized with multiple usage e.g. genotyping and southern hybridization analysis. Restriction enzyme identifies specific sequence from target nucleotide and makes a cut in DNA. The recognized sequences are mostly inverted repeat palindrome and differ with 4 and 8 nucleotides [55]. In REA, restriction enzyme is used for genotyping of DNA of target sample. The restriction enzymes are used to digest the sample to form many DNA fragments. Then small fragments can be separated employing polyacrylamide gel electrophoresis. After electrophoresis the pattern of bands displays subject's genotype $[56,57]$ (Figure 2).

\section{Gel Electrophoresis}

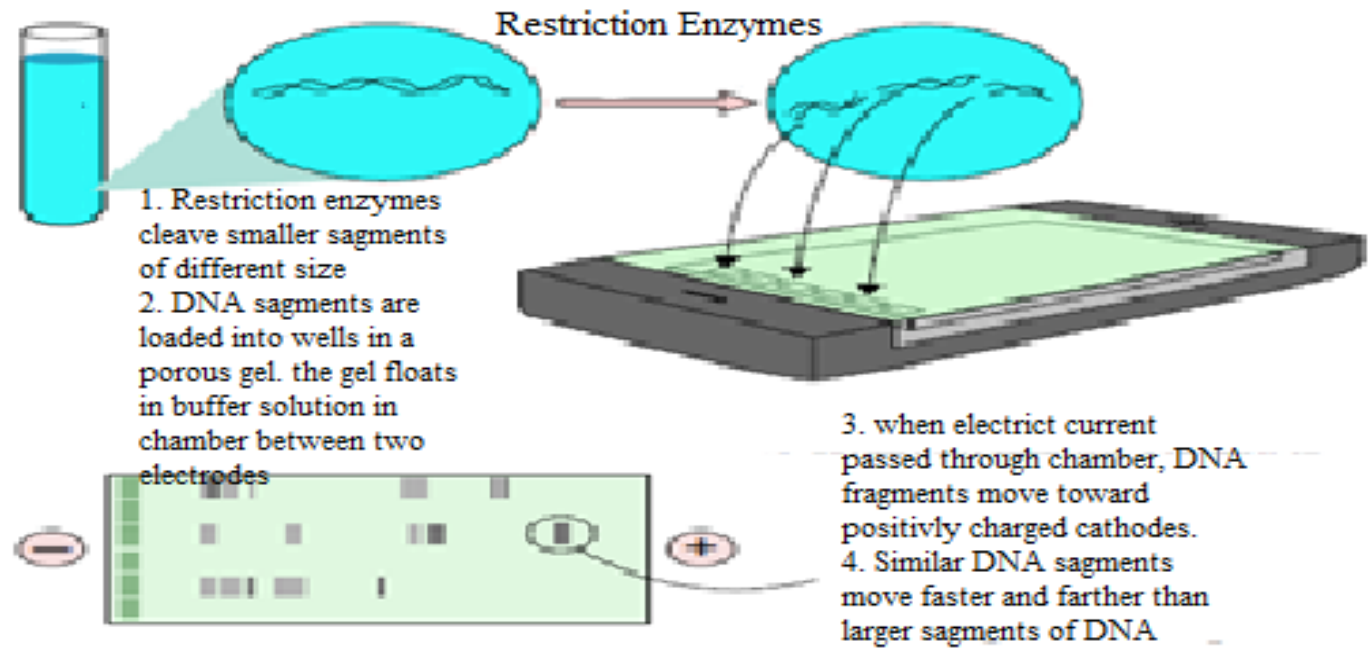

Figure 2. Show digestion of DNA and gel electrophoresis (source: [58])

\subsubsection{Pulse field gel electrophoresis (PFGE)}

Pulse field gel electrophoresis has been accomplished for studying genomic DNA of serotype O157 from separate sources [59, 60]. Using PFGE for recognition of O157:H7, first the focus were fixing in agarose, lysed, treated with protease to liberate the DNA, and digested this DNA with restriction endonuclease. The DNA fragments were separated using agarose gel (with ethodium bromide) on electric field apparatus. Afterward distained by water and visualized by Gel Doc analysis system [61]. The advantage of assay is generating of genetic data which could be analyzed 
statistically. However the limitation of approach is need of high professional experienced personals [62].

2.2. Partial genome genotyping

2.2.1. Restriction fragment length polymorphism (RFLP)

In this approach genomic DNA is digested by restriction enzyme and hybridized by a probe, design to identify DNA fragments complementary to probe [63]. By using RFLP for genotyping of O157:H7, first the DNA was purified then digested employing restriction enzyme. After electrophoresis the DNA fragments were separated. Afterward southern blot were performed by transferring DNA to Nytran membranes and hybridized along stx 1 and stx 2 probes [64, 65]. It was demonstrated that RFLP is simpler across REA, as the probes used are computable to required sequence, unlike RAE which use pattern of bands of whole DNA fragments [66]. The specific bands are used for detection of polymorphism and strains were subtype using size of bands. RFLP methods are used routinely but still have limitations over PFGE techniques [63, 67, 68].

\subsubsection{Random amplified polymorphic DNA (RAPD)}

In RAPD approach short random oligonecleotides of different sequences are used to amplify target sequences during PCR reaction for detection of targets [69]. Within assay, following DNA extraction the oligonucleotides can prepare a primer and each primer have the ability of generating specific DNA profile per sample. After amplification through PCR, the PCR products were isolated using gel electrophoresis and visualized by ultra violet trans illuminator. Results depend upon polymorphism of bands run on agarose gel [70]. The advantage of the approach is that it does not utilize probe and restriction enzyme of any kind, but utilize a DNA polymerase in PCR, that can tolerate high temperature.
High temperature is necessary for denaturation of target DNA and use constantly during amplification of DNA. Due to this feature the use of RAPDs is expanding [71]. Additionally RAPD does not require previous knowledge of target DNA sequences. But the disadvantage of RAPD is risk of adulterated DNA amplification and low reproducibility [72].

\subsection{Tandem repeat}

\subsubsection{Variable number tandem repeat} (VNTR)

VNTR is a device used for genotyping, providing data in easy and unambiguous design [62]. However its role in biology and its participation in evolutionary processes still remain impenetrable [73]. In this approach DNA contains many tandem repeat sequence (amplified by PCR) and product size determined by gel electrophoresis. The number of tandem repeat for each pathogenic loci including O157:H7 was determined on the bases of PCR product range [74].

\subsubsection{Multilocus variable number tandem} repeat analysis (MVTR)

This is DNA construct molecular typing approaches that can identify several repeats at multiple-variable number tandem repeat loci [63]. MVTR assay identify isolates from different outbreaks caused by serotype O157:H7. This method is easy and sensitive as PFGE for detection of serotype O157:H7 [69]. The approach introduces new, fast and safe methodologies for typing, so impact the health field of public. It has high resolution and reduced typing time so it is important in resolving complex outbreaks. The method is beneficial too for extensive automation. However the limitation of the assay is its high particularity, due to which lack of standardization for published assays [68].

\section{Phenotypic tests for $E$. coli O157:H7 3.1. Serotyping}

Full serotyping of stx producing E. coli is necessary because stx production has been 
investigated in strain of distinct serotypes. For full serotyping stx could be sent to reference laboratories for investigation of antisera in contrast to $\mathrm{O}$ antigens and $\mathrm{H}$ antigens. Mostly $\mathrm{O} 157$ strains are usual with flagellar $\mathrm{H} 7$ antigen, but non motile strain occur also been investigated lacking flagellar $\mathrm{H}$ antigen, a useful feature to distinguish between E. coli O157:H7 and non O157. Some stx producing E. coli belongs to enteropathogenic serogroups e.g. O26, O111, O55 and O128. Hence strains from these serogroups isolated from HUS or HC cases or outbreaks of diarrhea should be fully serotype or address to reference laboratories for additional tests to distinguish between VTEC [75].

\subsection{Phage typing}

A phage typing strategy was developed for investigation of epidemiology's caused by VT producing strains of EHCE O157:H7 [76]. The strategy employs 16 phages, recognized to use above 80 types [77-79]. In UK 24 phage types have been identified, while mostly strains belongs to phage type $1,2,4$ and 49. This assay is beneficial for $E$. coli $\mathrm{O} 157: \mathrm{H} 7$ but does not used for non O157 [80].

\subsection{Biotyping}

The biochemical features of VTEC are alike E. coli. As serotype O157:H7 lack the ability of fermenting sorbitol and production of beta-glucuronidase activity, biotyping have been proposed for confirmation of VTEC O157:H7 [81]. Different biotypes have been reported for VTEC O157 with regard of fermentation patterns [80].

\section{Biosensor}

The problem with rapid developed method is number of steps involve, including time consuming enrichment procedures. Biosensor are used ordinary but with many issues still remaining to be solved. An evanescent wave fiber optic biosensor has been used for identification of bacteria from ground beef samples [82]. Biosensor directs the light onto optical fiber probe by using a 635-nm laser diode. The optical fiber probes generate the evanescent wave. Fluorescent molecules are elevated and a part of emission re-couples in fiber probe. The fluorescent signals are detected and quantified by photodiode. A sandwich immunoassay can detect $9.0 * 10^{3} \mathrm{cfu} \mathrm{g}^{-1}$ for $25 \mathrm{~g}$ sample and $5.2 * 10^{2} \mathrm{cfu}^{-1}$ for $10 \mathrm{~g}$ samples. No false positive were obtained from results. Fiber optic biosensor has been used for detection of genomic DNA from $E$. coli and other coli forms [83]. A combination of PCR-acoustic wave sensor was added for detecting sequences of $E$. coli O157:H7 [84]. PCR was used for amplification of a unique sequence (509 bases) of pathogen and biotinylated probe to attach on sensor surface. This approach was suggested by author to be suitable for detection of bacterium from different sources e.g. water, food and clinical samples. Additionally it was suggested that this approach may assimilate for PCR based analysis of DNA. But achieving of this aim requires much more research. Leach et al. [85] studied spinach for presence of $E$. coli O157:H7 by using electro chemiluminescent (ECL) assay and fluorescence based cytometric bead assay. The ECL system detected >0.1 cfu of O157:H7 from per gram of spinach after enrichment of 5 hour, with total assay time of 6.5 hour. Cytometric bead assay detected $>0.1$ cfu per gram after enrichment of 7 hour, with total assay time of $>10 \mathrm{hrs}$. The author demonstrates both biosensor based assays are sensitive for rapid identification of EHEC O157:H7 on produce in time frames as compare to other testing formats. Biosensor is also used with surface plasmon resonance (SPR) for rapid detection of O157:H7. BIAcore, as shown in Figure 3 are most widely used SPR based systems using antibodies against O157:H7 [86-88]. GAI, L., 2011 used SPR biosensor for identification of O157:H7. Dextran 
modified sensor chip (CM5) and BIAcore 3000 (a SPR instrument) was used in this method. Following activation with use of EDC/NHS antibody for O157:H7 was immobilized on gold surface of SPR sensor, after that ethanolamine was injected and chip was organized for $E$. coli O157:H7. The detection limit found was $3 * 10^{5} \mathrm{cfu} X$ $\mathrm{ml}^{-1}$ for $E$. coli $\mathrm{O} 157: \mathrm{H} 7$ with time range of 5 to $7 \mathrm{~min}$. Regeneration results were effective and allowed the chip to be reused for more than 50 samples [89].

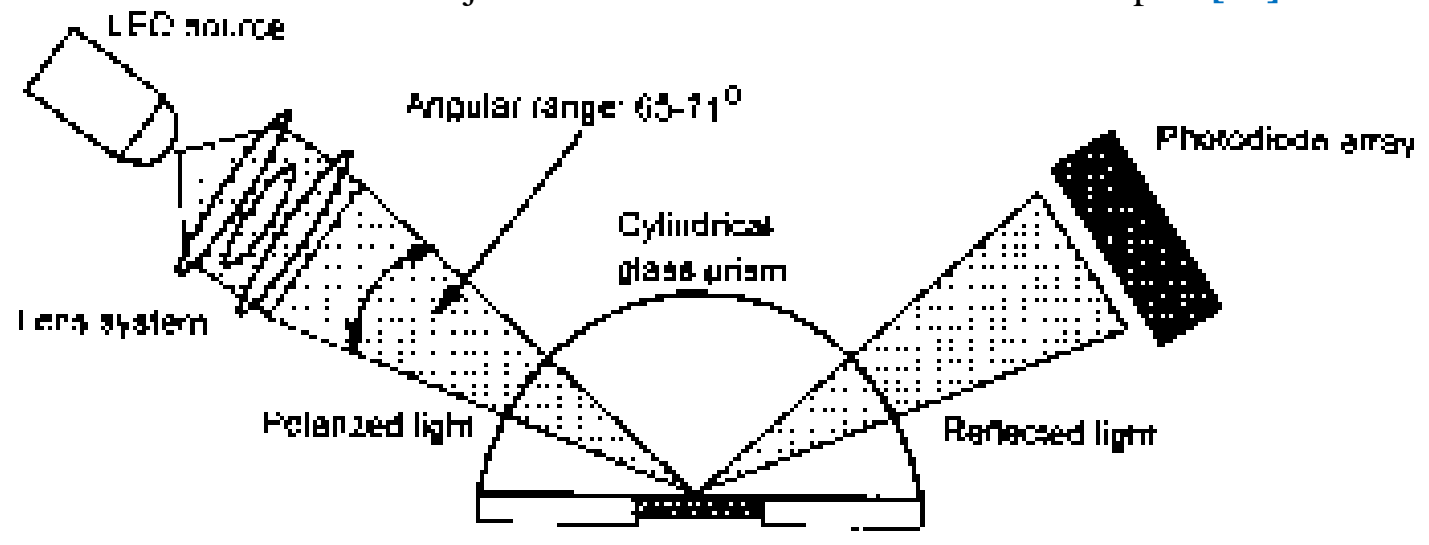

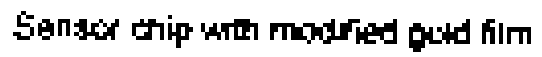

Figure 3. Show symbolic of BIACORE surface plasmon resonance spectrophotometer (source: [84])

\section{Fluorescence and microscopy}

E. coli $\mathrm{O} 157: \mathrm{H} 7$ has been detected via confocal scanning laser microscope [90]. Cells of O157:H7 were labeled with green fluorescent protein plasmid and treated with chlorine, acetic acid and hydrogen peroxide. Spectrophotometer was used to calculate the change in fluorescence magnitude, and confocal scanning microscope was used for observation of individual cells [91]. Different studies described a flow cytometric approach (FCM) for identification of $E$. coli $\mathrm{O} 157: \mathrm{H} 7$ and author described that FCM can detect 104 bacterial cells within few minutes, which is most sensitive and rapid then other methods [92]. In another study E. coli O157:H7 was modified using plasmid vector red-shifted green fluorescence protein (pEGFP) to show red shifted green fluorescence protein (EGFP) from aequorea victoria. Total cells and nonviable cells were used to determine the expression of EGFP at cellular by microscopic study of immunestained and membrane impermeable, dye stained cultures. The expression of EGFP was improved by sub culturing; reaching $83.4+/-$ $0.1 \%$, while the intensity of fluorescence varied among cells. EGFP show nonviable cells at low percentage. The percentage of EGFP expression was decreased by keeping culture plates at $4^{0} \mathrm{C}$, suggesting that during refrigeration same cells loss pEGFP expression. The culture suspensions were stored in deionized water at $4^{0} \mathrm{C}$ for 24 hours that decrease the percentage of EGFP expression and indicate some EGFP has been denatured. The application of EGFP was evaluated by using it as a marker for $E$. coli $\mathrm{O} 157: \mathrm{H7}$ in cauliflower, green leaf lettuce and tomato by using confocal scanning laser microscope. The number of O157:H7 cells identified by EGFP were equal to green leaf lettuce and cauliflower detected by immunostaining but found less for tomato. The study suggests EGFP can be used as a marker to detect attachment of $E$. coli $\mathrm{O} 157: \mathrm{H7}$ on cauliflower, green leaf lettuce but found unsuitable on tomato [93]. Oda et al. [94] used green fluorescent 
protein-labeled PP01 bacteriophage for detection of O157:H7. The phage small outer capsid (SOC) protein was used to present green fluorescent protein (GFP) on phage capsid. The DNA fragment throughout SOC was sequenced and magnified by PCR. GFP labeled PP01 phage was adsorbed not only on culturable cells of E. coli but also on viable but non culturable cells. The author suggested GFP labeled PP01 phage a specific, rapid and sensitive method for detection to all O157:H7. Recently Chen et al. [95] described indirect immunofluorescence approach for identification of E. coli O157:H7. The dry dropped silica nanoparticles (NPs) incorporated by water in oil (W/O) micro emulsion method combined with 3aminopropyltrithoxysilane (APTES) and fluorescein isothiocyanate (FITC) and polymerization reaction with carboxyethylsilanetriol sodium salt (CEOS). For detection of O157:H7, rabbit anti E. coli O157:H7 antibody was used as a primary antibody, afterward protein A with FITCdoped silica NPs (FSiNPs) was used for fluorescent signal generation. $E$. coli O157:H7 was detected in various beef samples with adequate results. FSiNPs are useful for pathogens in single amplified bioassay because of brighter fluorescence and higher photo stability.

\section{Emerging technologies}

\subsection{The microarray based assays}

Microarray, a device authorizes for detection of thousands of specific DNA/ RNA sequences on a small slide. These are called fast and rapid analyze to take place [84]. Nucleic acid microarrays developed for rapid recognition and genotyping of pathogenic bacteria [96]. Microarrays are also used for identification of bacterial gene also for pathogenic surveillance. For this requisition required labeled nucleic acid (Genomic DNA, rRNA etc, PCR products) are combined to clip of microarray, through which few types of direct or indirect fluorescent signal systems the target probe duplexes are detected. The comparative signal of each probe can be identified and quantified via confocal laser or by filtered light scanner [97] (Figure 4). Call and coworkers (2001) used mPCR and nucleic acid microarray for specific and sensitive detection of bacteria. The array contained 25-30-mer oligonucleotide probes interdependent to four objectives (intimin, stxl, stx 2 and heamolysin A). mPCR amplified the target DNA and amplicons were hybridized without any purification. The assay was 32 times more sensitive then gel electrophorases. The author suggested the combined use of immunomagnetic capture with PCR and microarray detected 55 cfu ml-1 of O157:H7 from chicken corpse wash water lacking pre-enrichment [98]. Viable but non culturable (VBNC) $E$. coli additionally act as a big warning, basically in potable water. Microarray has become advanced for sensitive detection of VBNC 0157:H7 from water. The $r f b E$ gene and $\mathrm{fliC}-\mathrm{H} 7$ gene were select as viable marker and identified by electronic microarray. From 1 liter (L) of river water 50 VBNC O157:H7 were detected [99]. The advantage of microarray is that the assay could not lie on length of identified PCR product. On need when microarray assay combined with PCR, improve the sensitivity of analysis, diagnostic and diagnostic specificity of O157:H7 [100]. But microarray approach has the limitation of expensive instruments and also requirements of special knowledge and instruction to remove useful information from enormous data generated [84]. Some technical issues included high framework interference mostly at short signal product and difference in organization of labeling nucleic acid with variation in experiments results from different laboratories can infect explanation of results. There for more researches needed 
on microarray based approaches before making this technology most able and sensitive for routinely used tests for identification of serotype O157:H7.

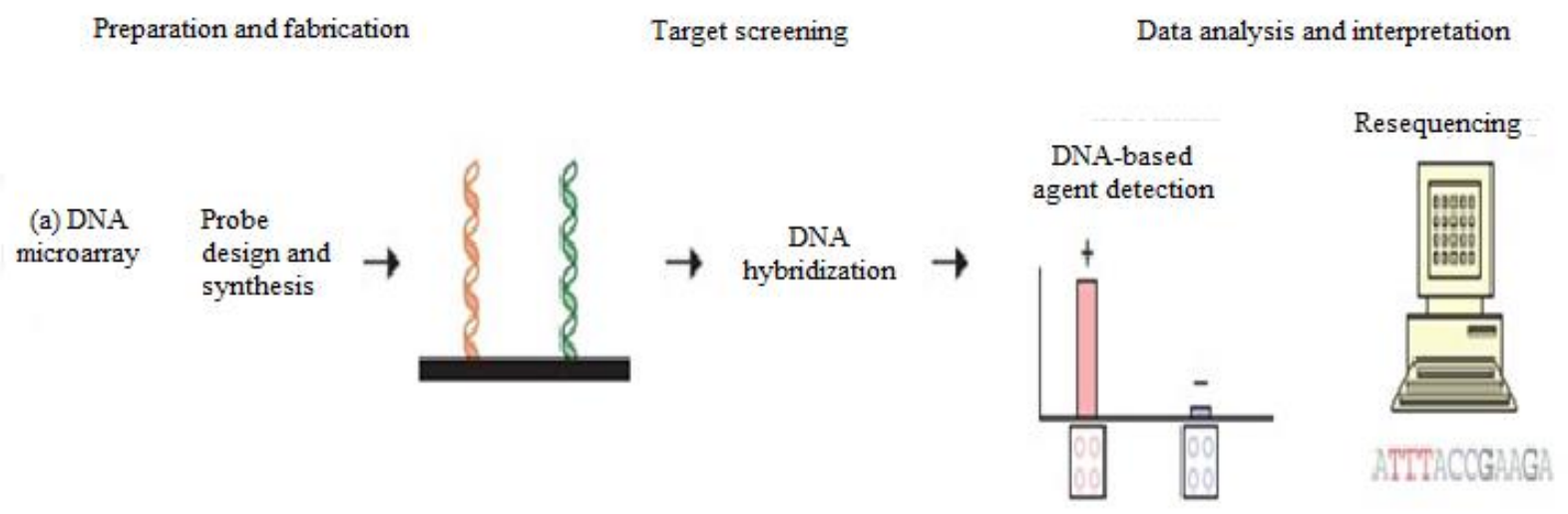

Figure 4. Simple representation of DNA based microarray (source: [58])

\subsection{Molecular beacons based assays}

Molecular beacons (MBs) are oligonucleotide probes and fluorescence upon hybridization [101]. The stem loop structure of these probes is their best essential feature and made by two oligodeoxynucleotide arms, first arm labeled along fluorophore and second along quencher. As loop hybridizes to target, the stem is open and due to which the quencher and fluorophore do not prolong close to one another and this show the outflow of fluorescence [102] (Figure 5). MBs are used routinely for identification of $E$. coli O157:H7. Fortin et al. [101] described realtime PCR and molecular beacons for recognition of EHEC O157:H7 from contaminated samples of milk and apple juice. MBs were sketched to identify $r f b E$ gene (26 bp). The particularity of MBs based PCR approach was estimated by studying of different EHEC, stx producing $E$. coli and also other bacterial species that cross react with serotype O157. All tested E. coli $\mathrm{O} 157$ were identified positive, while other species were not detected by the approach. The E. coli O157:H7 was detected when $>10^{2}$ cfu per ml was present in target sample. These methods enable quick and sensitive recognition of serotype O157:H7 [101]. Further studies bring improvement in MBs based methods. Kim et al. [97] described the molecular beacons based DNA microarray method for detection of $E$. coli O157:H7. The assay utilizes MBs that change color as a probe for visible detection of required sequence. Contrary from traditional fluorophore-quencher beacons based methods, the use of two fluorescence molecules permit visualization of both states (Hybridized and unhybridized) of beacons. This removes the risk of false negative signal for fluorophore-quencher beacons. Additionally the design of two colors allow to determine the absorption of target DNA from sample down to $<=1 \mathrm{ng}$ per microl. The author demonstrate the new designed method is applicable for simultaneous identification of hundreds of target DNA sequences by one test run, that use a series of beacons deactivated on single substrate in a contiguous format. 


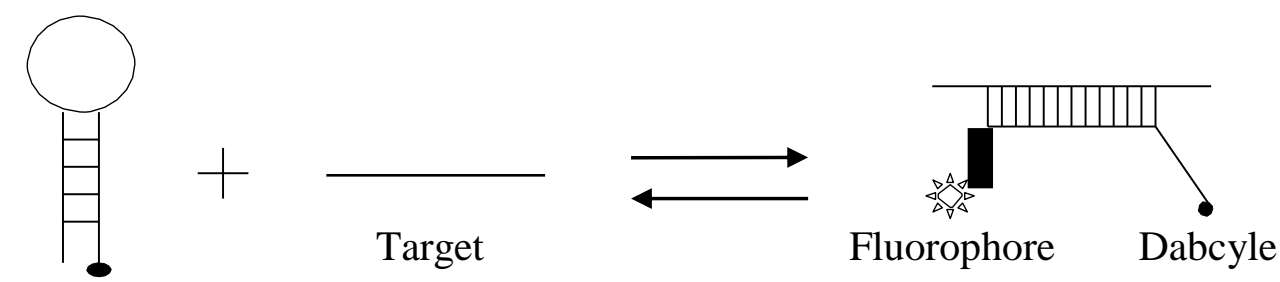

Molecular beacons (non-fluorescent)

Hybrid (fluorescent)

Figure 5. Showing principle of detection of hybrids along molecular beacons (source: [84])

\subsection{Lab-on-a-chip assays}

A lab-on-a-chip method has been newly recommended as best medium for real-time and portable diagnostics of medical. It is a tool that combines different laboratory purpose on one little platform. It involves handling of small volumes (Fluid), which initiate the area of micro fluidics. The technology employ a network of wells and channels engrave onto glass, polymer chips or silicon for building mini laboratories. The small volumes move through channels by electro kinetic forces. The merits of lab-ona-chip method are: speed of analysis, ease of use, high reproducibility and low sample and low reagent utilization [103]. Woolley et al. [104] reported the integration of PCR and capillary electrophoresis in a micro fabricated DNA analysis device. The method integrates thermal cycling with high-speed DNA separation by the CE chips. This system gives an assay of genomic Salmonella DNA in about 45 min. Several types of immunoassay could be implemented in Lab-on-a-chip platforms $[105,106]$. Here we will report few kinds of immunoassay lab-on-a-chip and individual function for identification of pathogenic bacteria. As generally ELISA is performed on microplate (96 microwells) and assess by microplate reader for results. In ELISA Labon-a-chip the wells are replaced with micro channel through which the target solution flows continuously. The antibodies are crippled on to inner surface of microchannel. The constant flow results in affective rinsing. Light is brightening to immobilized antibodies, while the signals from different side of micro channel are read by light sensor (Figure 6). Recently various unusual detection strategy have been determined for detection of food borne pathogens employing ELISA type lab-on-achip, which is most sensitive as to real time methods [103]. Guan et al. [107] use anti $E$. coli for bioluminescence based recognition of EHEC O157:H7. The detection limit found was $3.2 * 10^{1}$ cfu per ml with examination time of $20 \mathrm{~min}$. ELISA lab-ona-chip requires "labels" secondary antibodies, e.g. fluorescent dye, gold nanoparticles and chemiluminescent dye, with a couple of steps of rinsing. Many options advanced that don't require "labels" e.g. label unfastened immunoassay lab-on-achip. SPR in lab-on-a-chip is a well-known label-unfastened immunoassay lab-on-achip. In SPR lab-on-a-chip the gold surface is immobilized with antibodies. The chip of sensor is discovered to flow channel to ease the goal solutions and successive rinsing [103] (Figure 7). Fernández et al. [108] decided the antibiotic detection from milk using SPR lab-on-a-chip approach. The detection limit found becomes 1.1-2.1 ng per $\mathrm{mL}$ in diluted (five-fold) milk. Carbon nanotube (CNT) immunoassay lab-on-a-chip is popular "label-free" immunoassay lab-ona-chip with advantage of increased electronic properties and fast electrode kinetics. There are two kinds of CNTs, single walled CNT (SWCNT) and multi walled CNTs (MECNT) [103]. GarciaAljaro et al. [109] described CNTs based 
immunosensor for O157:H7. Detection limit found for was $10^{3}-10^{5} \mathrm{cfu}$ per $\mathrm{mL}$. These lab-on-a-chip methods can identify pathogens at the consumer level, in farms, distribution

systems

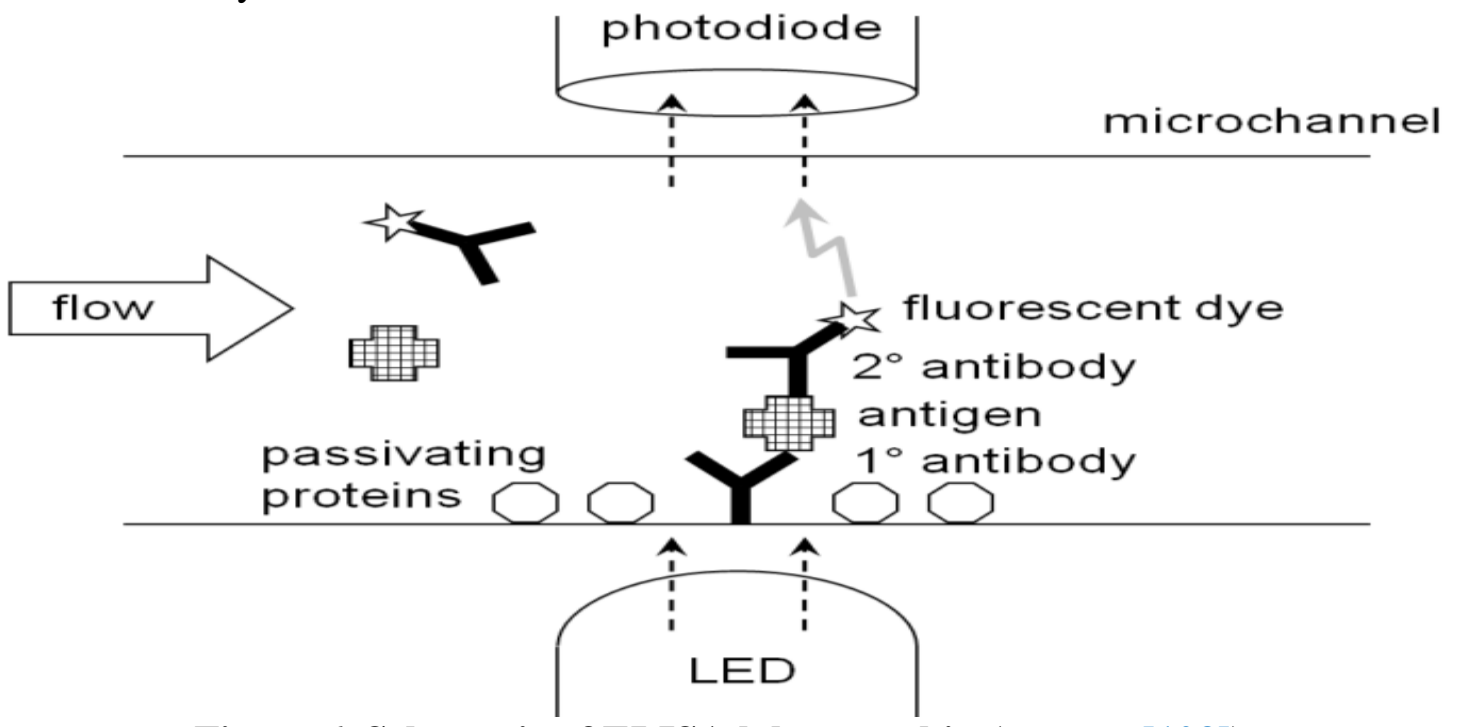

Figure 6. Schematic of ELISA lab-on-a-chip (source: [103])
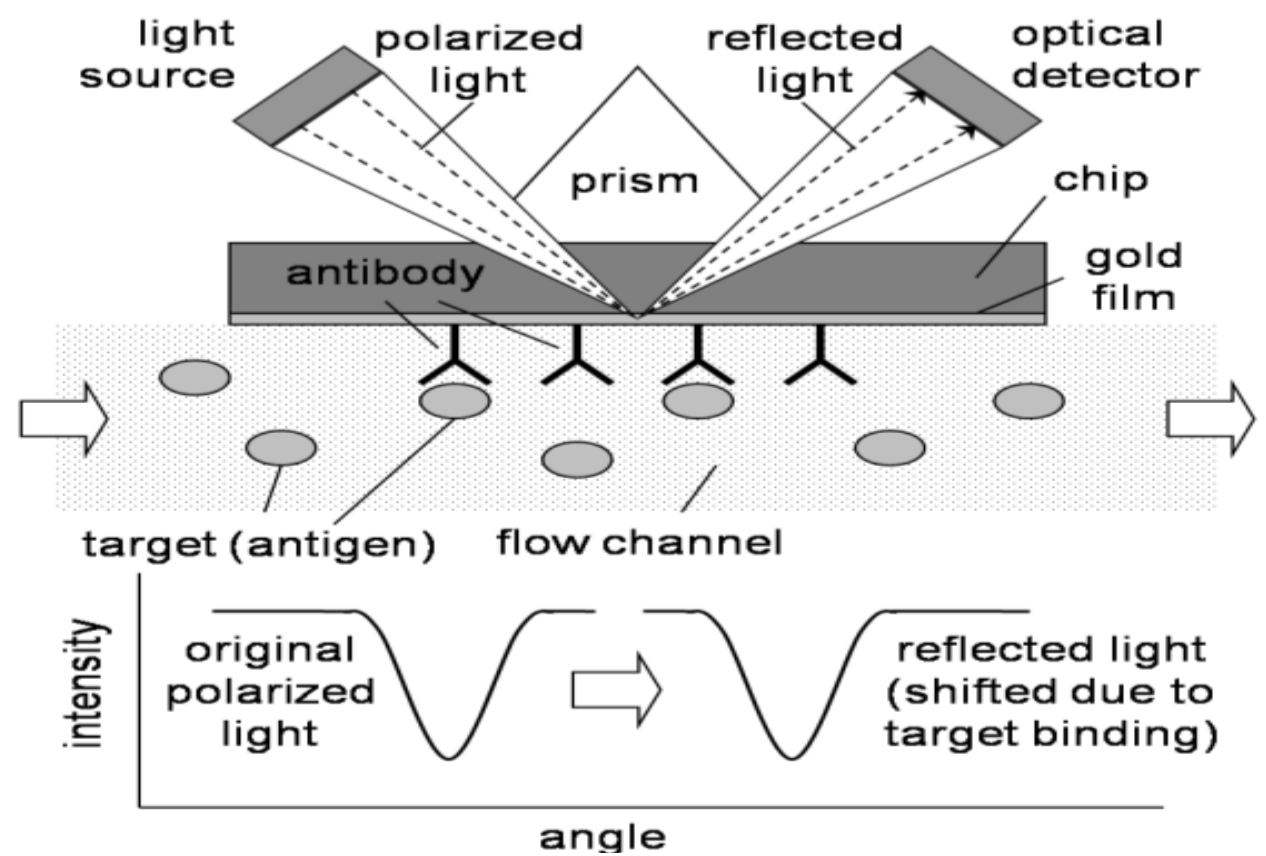

Figure 7. Schematic of SPR lab-on-a-chip (source: [103])

\section{Conclusion}

In this review we have examined different molecular approaches antiquated for detection of $E$. coli $\mathrm{O} 157: \mathrm{H} 7$. As a result of packaging/processing facilities. Quite now there are many difficulties to be designed prior to exercise these lab-on-a-chip sensors in different field demands [103]. 
of all the assays is given in Table 1 . Conventional assays are tedious and labor intensive. However application of molecular techniques rapidly and accurately full fills such limitations. PCR based detection methods (molecular methods) show notable advances and made detection easier. However the process could be reticent by food matrix and non-target DNA obtained from food origin. These complexes result in reaction frustration and false negative outcomes. DNA extraction was also famed to be a time consuming process. Finally it was noted that IMS or enrichment procedures are still needed to increase analysis of time. Among many variations of PCR, despite their drawbacks RT-PCR and mPCR made detection much easier for all researchers. DPCR omit the time consuming process of DNA extraction. Genomic techniques like PFGE and restricted fragment length polymorphism are described along with phenotyping (Table 1). As described above, Genomic techniques have many limitations e.g. require high professional experienced personals. Biosensor assays allot fast analysis time and real time measurement. As compared to other described methods, this method require less preparation time. Ordinarily enrichment procedures are not necessary. Biosensor is used with SPR for rapid detection. Fluorescent and microscopy have been described too for detection methods. Emerging technologies like microarray along with molecular beacons and Lab-on-achip assays described, allot rapid analysis and real time measurement without preenrichment. According to researchers, new designed improvements in molecular beacons are applicable for simultaneous identification of target DNA sequences by single run. However each method has its own advantages and limitations, decision for choice of detection method will require noticeable balance between some factors e.g. speed, specificity, sensitivity, discrimination power and accessibility of skilled personnel's. Consequently depend on the aloft conclusion; more research is needed to progress more specific, rapid and systematic techniques for diagnosing pathogenic bacteria including $E$. coli O157:H7.

Table 1. Summary of methods used for detection of $E$. coli $0157: H 7$

\begin{tabular}{|l|c|l|c|}
\hline \multicolumn{1}{|c|}{ Methods } & \multicolumn{1}{c|}{ Detection time } & \multicolumn{1}{c|}{ Detection limit } & References \\
\hline Plating / culturing & $1 \mathrm{day}$ to $1 \mathrm{week}$ & Low CFUs & {$[110]$} \\
\hline PCR & $2-24 \mathrm{~h}$ & $102-105 \mathrm{CFU} \mathrm{ml}^{-1}$ & {$[32]$} \\
\hline Multiplex PCR & $24 \mathrm{~h}$ & $1-2 \mathrm{CFU} \mathrm{m}^{-1}$ & {$[35]$} \\
\hline RT- PCR & $6-12 \mathrm{~h}$ & $107 \mathrm{CFU} \mathrm{ml}^{-1}$ & {$[45]$} \\
\hline Fibre optic biosensor & ca $30 \mathrm{~min}$ & $5.2 * 10^{2} \mathrm{CFU} \mathrm{g}^{-1}$ & {$[82]$} \\
\hline SPR biosensor & $1 \mathrm{~h}$ & $5 * 10^{7} \mathrm{CFU} \mathrm{ml}^{-1}$ & {$[111]$} \\
\hline Microarrays & $<1 \mathrm{~h}$ & $55 \mathrm{CFU} \mathrm{ml}^{-1}$ & {$[98]$} \\
\hline Molecular beacon & $1-6 \mathrm{~h}$ & $1-10^{3} \mathrm{CFU} \mathrm{ml}^{-1}$ & {$[101]$} \\
\hline Lab-on-a-chip & $16-45 \mathrm{~min}$ & $10^{2}-10^{4} \mathrm{organisms} \mathrm{ml}^{-1}$ & {$[112]$} \\
\hline
\end{tabular}

\section{Authors' contributions}

Conceived and designed the experiments: K Ullah \& B Tahira, Analyzed the Data: B Tahira, S Ali, S Nabi \& B Hajira, Wrote the paper: B Tahira, K Ullah \& A Muhammad.

\section{References}

1. Hofmann SL (1993). Southwestern Internal Medicine Conference: Shiga-like toxins in hemolytic-uremic syndrome and thrombotic thrombocytopenic purpura. Am J Med Sci 306(6): 398-406. 
2. Keusch GT \& Acheson DW (1997). Thrombotic thrombocytopenic purpura associated with Shiga toxins. Semin Hematol 34(2): 106-116.

3. Lansbury LE \& Ludlam H (1997). Escherichia coli O157: lessons from the past 15 years. J Infection 34(3): 189-193.

4. Parry SM \& Palmer SR (2000). The public health significance of VTEC 0157. J Appl Microbiol 88: 1-9.

5. Riley LW, Remis RS, Helgerson SD, McGee HB, Wells JG, Davis BR, Hebert RJ, Olcott ES, Johnson LM, Hargrett NT, Blake PA \& Cohen ML(1983). Hemorrhagic colitis associated with a rare Escherichia coli serotype. New Engl J Med 308(12): 681-685.

6. Bettelheim KA

Enterohaemorrhagic Escherichia coli a review. int Food hyg 7: 5-9.

7. Bettelheim KA (2000). Role of non-O157 VTEC. J Appl Microbiol 88(1): 38-50.

8. Gyles CL (2007). Shiga toxin-producing An overview. J Anim sci 85(13): 45-62.

9. Serna IVA \& Boedeker EC (2008). Pathogenesis and treatment of Shiga toxin-producing Escherichia coli infections. Curr Opin Gastroen 24(1): 38-47.

10. Griffin P, Olmstead L \& Petras R (1990). Escherichia coli 0157: H7associated colitis. Gastroenterology 99(1): 142-149.

11. Paton JC \& Paton AW (1998). Pathogenesis and diagnosis of Shiga toxin-producing Escherichia coli infections. Clin Microbiol Rev 11(3): 450-479.

12. Nataro JP \& Kaper JB (1998). Diarrheagenic Escherichia coli.Clin Microbiol Rev 11(1): 142-201.

13. Phillips AD \& Frankel G (2000). Intimin-mediated tissue specificity in enteropathogenic Escherichia coli interaction with human intestinal organ cultures. J Infect Dis 181(4): 14961500.

14. Boyce TG, Swerdlow DL \& Griffin PM (1995). Escherichia coli O157: H7 and the hemolytic-uremic syndrome. New Engl J Med 333(6): 364-368.

15. Centers for Disease Control and Prevention (CDC) (1997). Escherichia coli O157: H7 infections associated with eating a nationally distributed commercial brand of frozen ground beef patties and burgers Colorado. Morb Mortal Wkly Rep 46(33): 777-778.

16. Bell BP, Goldoft M, Griffin PM, Davis MA, Gordon DC, Tarr PI, Bartleson CA, Lewis JH, Barrett TJ, Wells JG, Baron R \& Kobayashi J (1994). A multistate outbreak of Escherichia coli O157: H7 associated bloody diarrhea and hemolytic uremic syndrome from hamburgers: the Washington experience. Jama 272(17): 1349-1353.

17. Slutsker L, Ries AA, Maloney K, Wells JG, Greene KD \& Griffin PM (1998). A nationwide case-control study of Escherichia coli O157: $\mathrm{H} 7$ infection in the United States. J Infect Dis 177(4): 962-966.

18. Rangel JM, Sparling PH, Crowe C, Griffin PM \& Swerdlow DL (2005). Epidemiology of Escherichia coli O157: H7 outbreaks, United States, 1982-2002. 11(4): 603-609.

19. Swerdlow DL, Woodruff BA, Brady RC, Griffin PM, Tippen S, Donnell HD, Geldreich M, Payne BJ, Meyer A, Wells JG, Greene KD Bright M, Bean NH \& Blake PA (1992). A waterborne outbreak in Missouri of Escherichia coli O157: H7 associated with bloody diarrhea and death.Ann Intern Med 117(10): 812-819.

20. Karmali MA (1989). Infection by verocytotoxin-producing Escherichia coli. Clin Microbiol Rev 2(1): 15-38. 
21. Griffin PM \& Tauxe RV (1991). The epidemiology of infections caused by Escherichia coli O157: H7, other enterohemorrhagic $E$. coli, and the associated hemolytic uremic syndrome. Epidemiol Rev 13(1): 60-98.

22. Mcgowan K, Wickersham E \& Strockbine N (1989). Escherichia coli 0157:

$\mathrm{H} 7$ from water. Lancet 333(8644): 967-968.

23. Centers for Disease Control and Prevention (CDC) (2005). Outbreaks of Escherichia coli O157: H7 associated with petting zoos--North Carolina, Florida, and Arizona, 2004 and 2005. Morb Mortal Wkly Rep 54(50): 1277-1280.

24. Durso LM, Reynolds K, Bauerr JN \& Keen JE (2005). Shiga-toxigenic Escherichia coli O157: H7 infections among livestock exhibitors and visitors at a Texas county fair. Vector-Borne Zoonotic Dis 5(2): 193-201.

25. Conner DE \& Kotrola JS (1995). Growth and survival of Escherichia coli O157: H7 under acidic conditions. Appl Environ Microb 61(1): 382-385.

26. Miller LG \& Kaspar CW (1994). Escherichia coli O157: H7 acid tolerance and survival in apple cider. $J$ Food Protect 57(6): 460-464.

27. Weagant SD, Bryant JL \& Bark DH (1994). Survival of Escherichia coli O157: $\mathrm{H7}$ in mayonnaise and mayonnaise-based sauces at room and refrigerated temperatures. $J$ Food Protect 57(7): 629-631.

28. Raghubeer EV, Ke JS, Campbell, ML \& Meyer RS (1995). Fate of Escherichia coli O157: $\mathrm{H} 7$ and other coliforms in commercial mayonnaise and refrigerated salad dressing. J Food Protect 58(1): 13-18.

29. Tarr PI (1995). Escherichia coli O157: H7: clinical, diagnostic, and epidemiological aspects of human infection. Clin Infect Dis 20(1): 1-10.

30. Jaykus LA (2003). Challenges to Developing Real-Time Methods to Detect Pathogens in Foods-Despite progress, real-time nucleic acid-based assays to detect pathogens in foods are not yet suitable for routine use. ASM 69(7): 341-347.

31. Winfield MD \& Groisman EA (2003). Role of nonhost environments in the lifestyles of Salmonella and Escherichia coli. Appl Environ Microbiol 69(7): 3687-3694.

32. Uyttendaele $M$, Van Boxstael S \& Debevere J (1999). PCR assay for detection of the E. coli O157: H7 eaegene and effect of the sample preparation method on PCR detection of heat-killed E. coli O157: $\mathrm{H} 7$ in ground beef. Int J Food Microbiol 52(1): 85-95.

33. Newton CR \& Graham A (1997). PCR, 2nd edn Bios Scientific.

34. Toma C, Lu Y, Higa N, Nakasone N, Chinen I, Baschkier A, Rivas $\mathrm{M} \&$ Iwanaga M (2003). Multiplex PCR assay for identification of human diarrheagenic Escherichia coli. Journal of clinical microbiology 41(6): 26692671.

35. Hu Y, Zhang Q \& Meitzler JC (1999). Rapid and sensitive detection of Escherichia coli 0157: H7 in bovine faeces by a multiplex PCR. J Appl Microbiol 87(6): 867-876.

36. Campbell GR, Prosser J, Glover A \& Killham K (2001). Detection of Escherichia coli O157: $\mathrm{H} 7$ in soil and water using multiplex PCR. J Appl Microbiol 91(6): 1004-1010.

37. Bélanger SD, Boissinot M, Ménard C, Picard FJ \& Bergeron MG (2002). Rapid detection of Shiga toxinproducing bacteria in feces by multiplex PCR with molecular beacons on the 
smart cycler. J Clin Microbiol 40(4): 1436-1440.

38. Oberst RD, Hays MP, Bohra LK, Phebus RK, Yamashiro CT, PaszkoKolva C \& Gillespie JR (1998). PCRbased DNA amplification and presumptive detection of Escherichia coli O157: $\mathrm{H} 7$ with an internal fluorogenic probe and the $5^{\prime}$ nuclease (TaqMan) assay. Appl Environ Microbiol 64(9): 3389-3396.

39. Sharma VK (2002). Detection and quantitation of enterohemorrhagic Escherichia coli $\mathrm{O} 157, \mathrm{O} 111$, and $\mathrm{O} 26$ in beef and bovine feces by real-time polymerase chain reaction. $J$ Food Protect 65(9): 1371-1380.

40. Reischl U Youssef MT, Kilwinski J, Lehn N, Zhang WL, Karch H \& Strockbine NA (2002). Real-time fluorescence PCR assays for detection and characterization of Shiga toxin, intimin, and enterohemolysin genes from Shiga toxin-producing Escherichia coli. J Clin Microbiol 40(7): 25552565.

41. Ibekwe AM, Watt PM, Grieve CM, Sharma VK \& Lyons SR (2002). Multiplex fluorogenic real-time PCR for detection and quantification of Escherichia coli O157: $\mathrm{H} 7$ in dairy wastewater wetlands. Appl Environ Microbiol 68(10): 4853-4862.

42. Mackay IM, Arden KE \& Nitsche A (2002). Real-time PCR in virology. Nucleic acids research 30(6): 12921305.

43. Spano G, Beneduce L, TerziV, Stanca AM \& Massa S (2005). Real-time PCR for the detection of Escherichia coli O157: $\mathrm{H7}$ in dairy and cattle wastewater. Lett Appl Microbiol 40(3): 164-171.

44. Moon SH, Lee YJ, Park SY, Song KY, Kong MH \& Kim JH (2011). The Combined Effects of Ginkgo Biloba
Extracts and Aspirin on Viability of SKN-MC, Neuroblastoma Cell Line in Hypoxia and Reperfusion Condition. Journal of Korean Neurosurgical Society 49(1): 13-19.

45. Yaron S \& Matthews KR (2002). A reverse transcriptase-polymerase chain reaction assay for detection of viable Escherichia coli $\mathrm{O} 157: \mathrm{H7}$ : investigation of specific target genes. $J$ Appl Microbiol 92(4): 633-640.

46. De Wet SC, Denman SE, Sly L \& McSweeney CS (2008). An improved method for RNA extraction from carcass samples for detection of viable Escherichia coli O157: H7 by reverse-transcriptase polymerase chain reaction. Lett Appl Microbiol 47(5): 399-404.

47. Fode-Vaughan KA, Wimpee CF, Remsen CC \& Collins MP (2001). Detection of bacteria in environmental samples by direct PCR without DNA extraction. Biotechniques 31(3): 598607.

48. Fode-Vaughan KA, Maki JS, Benson JA \& Collins MLP (2003). Direct PCR detection of Escherichia coli O157: H7. Lett Appl Microbiol 37(3): 239-243.

49. Swaran YC (2014). Direct PCR in Forensic Science-An overview. Malaysian Journal of Forensic Sciences 5(2): 6-12.

50. Qualicon http://www.qualicon.com/abx.htm

51. Fritschel SJ (2001) Dupont ${ }^{\mathrm{TM}}$ BAX ${ }^{\circledR}$ system precise and powerful molecular pathogen detection: Food Diagnostics.

52. Johnson JL, Brooke CL \& Fritschel SJ (1998). Comparison of the BAX for screening/E. coli O157: $\mathrm{H} 7$ method with conventional methods for detection of extremely low levels of Escherichia coli O157: H7 in ground beef. Appl Environ Microbiol 64(11): 4390-4395. 
53. Shearer AEH, Strapp CM \& Joerger RD (2001). Evaluation of a PCR-based system for detection of Salmonella enteritidis, Escherichia coli O157: H7, and Listeria monocytogenes on fresh fruits and vegetables. $J$ Food Protect 64: 788-795.

54. Kessler C \& Manta V (1990). Specificity of restriction endonucleases and DNA modification methyltransferases, a review (edition 3). Gene 92(1-2): 1-240.

55. Clark DP \& Pazdernik NJ (2013) Molecular biology. (2nd Edn). Amsterdam. Elsevier Academic Press USA.

56. Singleton P \& Sainsbury D (2006) Dictionary of Microbiology and Molecular Biology. (3rd edn). John Wiley \& Sons Ltd USA.

57. Roberts RJ (1981) Restriction and modification enzymes and their recognition sequences. Nucleic Acids Res 9: 75-96.

58. Foxman B (2010). Molecular tools and infectious disease epidemiology. Academic Press.

59. Harsono KD, Kaspar CW \& Luchansky JB (1993). Comparison and genomic sizing of Escherichia coli O157: H7 isolates by pulsed-field gel electrophoresis. Appl Environ Microbiol 59(9): 3141-3144.

60. Böhm H \& Karch H (1992). DNA fingerprinting of Escherichia coli O157: H7 strains by pulsed-field gel electrophoresis. J Clin Microbiol 30(8): 2169-2172.

61. Avery SM, Liebana E, Reid CA, Woodward MJ \& Buncic S (2002). Combined use of two genetic fingerprinting methods, pulsed-field gel electrophoresis and ribotyping, for characterization of Escherichia coli O157 isolates from food animals, retail meats, and cases of human disease. $J$ Clin Microbiol 40(8): 2806-2812.

62. OIE (2008) Vero cytotoxigenic Escherichia coli.

63. O'Sullivan J, Bolton DJ, Duffy G, Baylis C, Tozzoli R, Wasteson Y \& Lofdahl S (2007). Methods for detection and molecular characterization of pathogenic Escherichia coli. The Pathogenic Escherichia coli Network. Ashtown Food Research Centre, Teagasc, Ashtown Ireland 1-32.

64. Gates KW (2011). Rapid Detection and Characterization of Foodborne Pathogens by Molecular Techniques: Robert E. Levin. Boca Raton, FL, USA. CRC Press, Taylor and Francis Group, 2010. 608 pages. J Aquat Food Prod T 20(1): 108-113.

65. Kudva IT, Hatfield PG \& Hovde CJ (1997). Characterization of Escherichia coli O157: H7 and other Shiga toxinproducing $E$. coli serotypes isolated from sheep. J Clin Microbiol 35(4): 892-899.

66. Durr PA, Clifton-Hadley RS \& Hewinson RG (2000). Molecular epidemiology of bovine tuberculosis II. Applications of genotyping. Rev Sci Tech Oie 19(3): 689-701.

67. Ramazanzadeh R \& McNerney R (2007). Variable Number of Tandem Repeats (VNTR) and its application in bacterial epidemiology. Pak J Biol Sci 10(16): 2612-2621.

68. Lindstedt BA, Torpdahl M, Vergnaud G, Le Hello S, Weill FX, Tietze E,Malorny B, Prendergast DM, Ní Ghallchoir E, Lista RF, Söderlund R, Börjesson $\mathrm{S}$, Åkerström $\mathrm{S} \&$ Schouls LM (2012). Use of multilocus variablenumber tandem repeat analysis (MLVA) in eight European countries, 2012. Euro Surveill 18(4): 20385.

69. Vogel L, Van-Oorschot E, Maas HME, Minderhoud B \& Dijkshoorn L (2000). 
Epidemiologic typing of Escherichia coli using RAPD analysis, ribotyping and serotyping. Clin Microbiol Infec 6(2): 82-87.

70. Kilic A, Muz A, Ertas HB \& Ozbey G (2009). Random amplified polymorphic DNA (RAPD) analysis of Escherichia coli isolated from chickens. FU Sag Bil Vet Derg 23(1): 1-4.

71. Chansiripornchai N, Ramasoota P, Sasipreeyajan J \& Svenson SB (2001). Differentiation of avian pathogenic Escherichia coli (APEC) strains by random amplified polymorphic DNA (RAPD) analysis. Vet Microbiol 80(1) 75-83.

72. Kanungo S (2009). A simplified analysis of different Escherichia coli strains by using RAPD technique. Not Bot Horti Agrobot Cluj Napoca 37(2): 257-260.

73. Mazars E, Lesjean S, Banuls AL, Gilbert M, Vincent V, Gicquel B, Tibayrenc M, Locht C \& Supply P (2001). High-resolution minisatellitebased typing as a portable approach to global analysis of Mycobacterium tuberculosis molecular epidemiology. Proc Natl Acad Sci 98(4): 1901-1906.

74. Adair DM, Worsham PL, Hill KK, Klevytska AM, Jackson PJ, Friedlander AM \& Keim P (2000). Diversity in a Variable-Number Tandem Repeat from Yersinia pestis. J Clin Microbiol 38(4): 1516-1519.

75. Gross RJ \& Rowe B (1985). Serotyping of Escherichia coli. Spec Publ Soc Gen Microbiol 345-363.

76. Ahmed R, Bopp C, Borczyk A \& Kasatiya S (1987). Phage-typing scheme for Escherichia coli O157: H7. J Infect Dis 155(4): 806-809.

77. Frost JA, Smith HR, Willshaw GA, Scotland SM, Gross RJ \& RoweB (1989). Phage-typing of Vero-cytotoxin (VT) producing Escherichia coli $\mathrm{O} 157$ isolated in the United Kingdom. Epidemiol Infect 103(01): 7381.

78. Frost JA, Cheasty T, Thomas A \& Rowe B (1993). Phage typing of Vero cytotoxin-producing Escherichia coli $\mathrm{O}$ 157 isolated in the United Kingdom: 1989-91. Epidemiol Infect 110(03): 469-475.

79. Khakhria R, Duck D \& Lior H (1990). Extended phage-typing scheme for Escherichia coli 0157: H7 .Epidemiol Infect 105(03): 511-520.

80. Vernozy-Rozand C, Mazuy C, Ray-Gueniot S, Boutrand-Loeï S, Meyrand A \& Richard Y (1997). Detection of Escherichia coli $\mathrm{O} 157$ in French food samples using an immunomagnetic separation method and the VIDASTM E. coli O157. Lett Appl Microbiol 25(6): 442-446.

81. Aleksić S, Karch H \& Bockemühl J (1992). A Biotyping Scheme for Shigalike (Vero) Toxin-producing Escherichia coli 0157 and a List of Serological Cross-reactions between O157 and Other Gram-negative Bacteria's. Zentralbl Bakteriol 276(2): 221-230.

82. DeMarco DR \& Lim DV (2002). Detection of Escherichia coli O157: H7 in 10-and 25-gram ground beef samples with an evanescent-wave biosensor with silica and polystyrene waveguides. $J$ Food Protect 65(4): 596-602.

83. Almadidy A, Watterson J, Piunno PA, Raha S, Foulds IV, Horgen PA, Castle A \& Krull U (2002). Direct selective detection of genomic DNA from coliform using a fiber optic biosensor. Anal Chim Acta 461(1): 3747.

84. Deisingh AK \& Thompson M (2001). Sequences of E. coli O157: H7 detected by a PCR-acoustic wave sensor 
combination. Analyst 126(12): $2153-$ 2158.

85. Leach KM, Stroot JM \& Lim DV (2010). Same-day detection of Escherichia coli O157: H7 from spinach by using electrochemiluminescent and cytometric bead array biosensors. Appl Environ Microbiol 76(24): 8044-8052.

86. Jönsson U, Fägerstam L, Ivarsson B, Johnsson B, Karlsson R, Lundh K, Löfås S, Persson $\mathrm{B}$, Roos $\mathrm{H} \quad$ \& Rönnberg I (1991). Real-time biospecific interaction analysis using surface plasmon resonance and a sensor chip technology. Bio Techniques 11(5): 620-627.

87. Jönsson U \& Malmqvist M (1992) Realtime biospecific interaction analysis. The integration of surface plasmon resonance detection, general biospecific interface chemistry and microfluidics into one analytical system. $A d v$ Biosensors 2: 291-236.

88. Fratamico PM, Strobaugh TP, Medina MB \& Gehring AG (1998). A surface plasmon resonance biosensor for realtime immunologic detection of Escherichia coli O157: H7. New techniques in the analysis of foods 103112 Springer US.

89. GAI L (2011). Rapid detection of Escherichia coli O157: H7 using surface plasmon resonance (SPR) biosensor. Spectrosc Spect Anal 31(10): 2598-2601.

90. Burnett SL \& Beuchat LR (2002). Comparison of methods for fluorescent detection of viable, dead, and total Escherichia coli O157: H7 cells in suspensions and on apples using confocal scanning laser microscopy following treatment with sanitizers. Int J food microbiol 74(1): 37-45.
91. Magni MV (Ed) (2010). Detection of bacteria, viruses, parasites and fungi: Bioterrorism prevention. Springer.

92. Yamaguchi N, Sasada M, Yamanaka M \& Nasu M (2003). Rapid detection of respiring Escherichia coli O157: H7 in apple juice, milk, and ground beef by flow cytometry. Cytometry part A 54(1): 27-35.

93. Takeuchi K \& Frank JF (2001). Expression of red-shifted green fluorescent protein by Escherichia coli O157: H7 as a marker for the detection of cells on fresh produce. J Food Protect 64(3): 298-304.

94. Oda M, Morita M, Unno H \& Tanji Y (2004). Rapid detection of Escherichia coli O157: $\mathrm{H} 7$ by using green fluorescent protein-labeled PP01 bacteriophage. Appl Environ Microbiol 70(1): 527-534.

95. Chen ZZ, Cai L, Chen MY, Lin Y, Pang DW \& Tang HW (2015). Indirect immunofluorescence detection of $E$. coli O157: H7 with fluorescent silica nanoparticles. Biosens Bioelectron 66: 95-102.

96. Call DR (2005). Challenges and opportunities for pathogen detection using DNA microarrays. Crit Rev Microbiol 31(2): 91-99.

97. Kim H, Kane MD, Kim S, Dominguez W Applegate BM \& Savikhin S (2007). A molecular beacon DNA microarray system for rapid detection of $E$. coli O157: H7 that eliminates the risk of a false negative signal. Biosens Bioelectron 22(6): 1041-1047.

98. Call DR, Brockman FJ \& Chandler DP (2001). Detecting and genotyping Escherichia coli O157: H7 using multiplexed PCR and nucleic acid microarrays. Int J food microbiol 67(1): 71-80.

99. Liu Y, Gilchrist A, Zhang J \& Li XF (2008). Detection of viable but 
nonculturable Escherichia coli O157: $\mathrm{H} 7$ bacteria in drinking water and river water. Appl Environ Microbiol 74(5): 1502-1507.

100. Shah DH, Shringi S, Besser TE \& Call DR (2010) Molecular Detection of Food Borne Pathogens. CRC Press Taylor \& Francis Group USA 309-369.

101. Fortin NY, Mulchandani A \& Chen W (2001). Use of real-time polymerase chain reaction and molecular beacons for the detection of Escherichia coli O157: H7. Anal biochem 289(2): 281288.

102. Brown LJ, Cummins J, Hamilton A \& Brown T (2000). Molecular beacons attached to glass beads fluoresce upon hybridisation to target DNA. Chem Commun (7): 621-622.

103. Yoon JY \& Kim B (2012). Lab-on-achip pathogen sensors for food safety. Sensors 12(8): 10713-10741.

104. Woolley AT, Hadley D, Landre P, deMello AJ, Mathies RA \& Northrup MA (1996). Functional integration of PCR amplification and capillary electrophoresis in a microfabricated DNA analysis device. Analytical Chemistry 68(23): 4081-4086.

105.Skottrup PD, Nicolaisen M \& Justesen AF (2008). Towards on-site pathogen detection using antibody-based sensors. Biosens Bioelectron 24(3): 339-348.

106. Mujika M, Arana S, Castano E, Tijero M, Vilares R, Ruano-Lopez JM, Cruz A, Sainz L \& Berganza J (2009). Magnetoresistive immunosensor for the detection of Escherichia coli O157: H7 including a microfluidic network. Biosens Bioelectron 24(5): 1253-1258.
107. Guan X, Zhang HJ, Bi, YN, Zhang L \& Hao DL (2010). Rapid detection of pathogens using antibody-coated microbeads with bioluminescence in microfluidic chips. Biomed microdevices 12(4): 683-691.

108. Fernández F, Hegnerová K, Piliarik M, Sanchez-Baeza F, Homola J \& Marco MP (2010). A label-free and portable multichannel surface plasmon resonance immunosensor for onsite analysis of antibiotics in milk samples.Biosens Bioelectron 26(4): 1231-1238.

109. García-Aljaro C, Cella LN, Shirale DJ, Park M, Muñoz FJ, Yates MV \& Mulchandani A (2010). Carbon nanotubes-based chemiresistive biosensors for detection of microorganisms. Biosens Bioelectron 26(4): 1437-1441.

110. Silk TM \& Donnelly CW (1997). Increased detection of acidinjured Escherichia coli O157:H7 in autoclaved apple cider by using nonselective repair on trypicase soy agar. Journal of Food Protection 60: 1483-1486.

111. Fratamico PM, Strobaugh TP, Medina MB \& Gehring AG (1997). A Surface Plasmon Resonance Biosensor for Realtime Immunologic Detection of Escherichia coli O157:H7, New Techniques in the Analysis of Foods 103-112.

112. Belgrader $P$, Bennett $W$, Hadley $D$, Long G, Mariella R, Milanovich F, Nasarabadi S \& Nelson W et al. (1998) Rapid pathogen detection using a microchip PCR array instrument. Clinical Chemistry 44(10): 2191-2194. 